\title{
ポリピロールナノ分散液を用いる新無電解めっき
}

\author{
石黒 正 ${ }^{\mathrm{a}}$, 原澤 純一 ${ }^{\mathrm{a}}$, 芦澤 弘樹 ${ }^{\mathrm{a}}$ \\ aアキレス(株) 研究開発本部 ( ⿳ 326-8511＼cjkstart栃木県足利市借宿町 668)
}

\section{New Electroless Plating using Nano Dispersion of Polypyrrole}

Tadashi ISHIGURO ${ }^{\text {a }}$, Junichi HARASAWA ${ }^{\text {a }}$ and Hiroki ASHIZAWA ${ }^{\text {a }}$

${ }^{a}$ R\&D Head Office, Achilles Corporation(668, Kariyado-cho, Ashikaga-shi, Tochigi 326-8511)

Keywords : Polypyrrole, Electroless Plating, Roll-to-Roll, Printing

\section{1.はじめに}

$\mathrm{ABS}$ 樹脂に代表されるプラスチック(樹脂) 上へのめっき 技術は, (1)クロム酸/硫酸の混酸を用いて樹脂表面に微細な 凹凸を形成するエッチング工程，(2)金属触媒の吸着工程，(3) 無電解めっき工程からなる方法である。この方法では, エッ チング工程により樹脂表面に形成された凹凸にめっき金属が 物理的に引っかかること (アンカー効果)により良好な密着性 が得られることが知られている。しかしながら，このような エッチング工程を必要とするめつき技術には, いくつかの課 題や要望が挙げられている。

装飾めっきに代表されるプラスチック成形品の分野では, $\mathrm{ABS}$ 樹脂以外のプラスチックにおいて密着力が低いことが 課題であり，煩雑なエッチング処理を行わずに密着の良い めっきができないかという要望がある。従来のプラスチック めっきの基材はおよそ $90 \%$ 以上が $\mathrm{ABS}$ 樹脂に限られている が, 汎用プラスチック (PP などのオレフィン, PVC, PS など) や高付加価值の機能特性を有するエンプラ樹脂 (PET, PA, PC， PEEK，LCP など)にも密着強度の高いめっき技術が求 められている ${ }^{1)}$ 。また, 近年の環境問題への重要性が増す中 で，エッチング工程で使用する環境負荷物質である 6 価クロ ムを用いないめっき技術が求められている。

一方, プリント配線板に代表される電子機器の分野では, 信号処理速度の高速化, 通信周波数の高周波化への対応の中 で，めっき膜の表皮効果の影響が無視できなくなり，粗化処 理による樹脂とめっき膜界面の数 $\mu \mathrm{m}$ の凹凸が通信性能に大 きな影響を及ぼすことがわかってきた。そのため，平滑性の 高い樹脂表面への密着の良いめっき膜が求められている ${ }^{2)}$ 。 さらには，コストや環境負荷の観点から，通信に必要な回路 部のみにめっきを施すことができるパターンめっきの技術が 求められている。

本解説文では, 従来のプラスチックめっき技術の課題を解 決する手法として, ポリピロールを用いた新無電解めっきプ ロセス ${ }^{3)}$ を見出したので紹介する。

\section{2. ポリピロールナノ分散液について}

当社では, 1993 年より導電性高分子の 1 つであるポリピ ロールを用いた商品を上市し, 現在, 主力事業の 1 つとなっ ている。これらの商品は, ポリピロールの導電性を利用して 部品・樹脂成形品・フィルムに帯電防止機能を持たせたもの である(製品名：ST ポリ)。

その開発の中で, 不溶性であるポリピロールを弊社独自の 重合技術を用いて，さらには，特殊な分散安定剤を用いるこ とにより，一般的な有機溶媒(トルエン・酢酸ブチル)にナノ サイズの微粒子として, 安定分散させることに成功した（以下， ポリピロールナノ分散液と記載) ${ }^{4)}$ ７)。本解説文で紹介する 新めっき技術は, ポリピロールナノ分散液を帯電防止用途と は異なるポリピロールの重合条件により，プラスチックめっ きの下地材として適した分散粒子へと特性を変えたポリピ ロールナノ分散液を用いたものである。次項でポリピロール を用いた無電解めっき技術について紹介する。

\section{3. ポリピロールナノ分散液を用いた無電解めっき技術}

ポリピロールナノ分散液を用いた新めっきプロセスの工程 を図 1 に示す。この新めっきプロセスでは, 被めっき物(基材) にポリピロール塗料を塗布するところから始まる。このポリ ピロール塗料はポリピロールナノ分散液とバインダー成分か

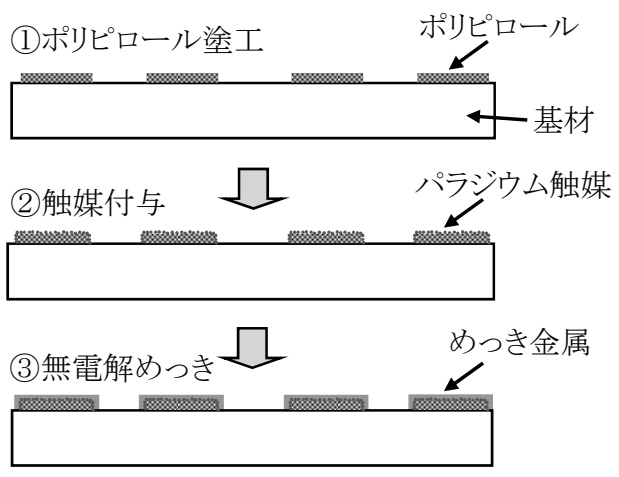

図1 ポリピロール法での無電解めっきプロセス 


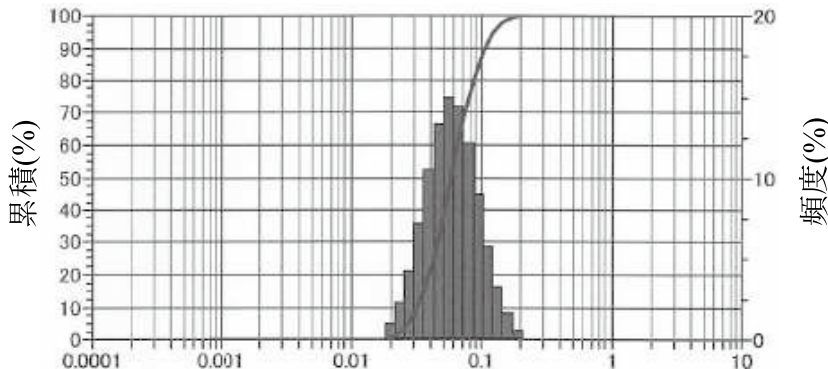

粒径 $(\mu \mathrm{m})$

図2 ポリピロールナノ分散液の粒径分布

ら構成される。バインダーは，基材によって選択することが でき，基材と塗膜の密着性を高める効果がある。また，ポリ ピロールナノ分散液中のポリピロール微粒子は, 図 2 に示す ように平均粒子径が約 $50 \mathrm{~nm}$ で正規分布しており，その分散 状態を保持できるようなバインダーの選定も重要である。

続いて，ポリピロール塗料を塗工した基材を，低濃度のパ ラジウムイオン水溶液に浸漬することで，ポリピロールの酸 化還元作用によって塗工された部分にのみに選択的に無電解 めっきの触媒であるパラジウム金属が強固に化学吸着する。 その後，一般的な無電解めっき浴に浸漬することにより，塗 工された部分(パラジウムが付着した部分)にめっきが析出す る。基材とポリピロール塗膜との密着は，基材に密着するバ インダー成分を選定することによって得られる。ポリピロー ルナノ分散液を用いためっきプロセスの特徵は，以下の 3 点 である。

1)ポリピロール塗料塗工部のみにめっきが析出する(パター ンめっきが可能)

2) 無電解めっきが難しい樹脂へのめっきが可能 (PET，ポリ カーボネート (PC), PP, PVCなど)

3)クロム酸などによる樹脂エッチング(表面粗化)が不要とな る。

現在，この技術を用いて幅広い分野への製品展開を検討し ている ${ }^{8) \sim 10)}$ 。

\section{4. ロール to ロール生産方式}

当社では, 前述の特徵を活かしてロール to ロール方式で のパターンめっきフィルムの生産技術を検討している。ロー ル to ロール生産方式は, 通常めっき処理で行われるバッチ 処理と比較して, 連続生産が可能なことから生産性が高くコ ストダウンが可能である ${ }^{11)}$ 。この生産工程には，1）ポリピ ロール塗料の印刷工程, 2) 連続無電解めっき工程の 2 工程が あり，それぞれの概略を説明する。

\section{1 ポリピロール塗料のパターン印刷}

本技術のパターンめっきは，ポリピロール塗工部のみに， 無電解めっきの触媒金属であるパラジウムが吸着することに より，選択的なめっきができる原理を用いたものである。そ のため，ポリピロール塗料を目的パターンに合わせて精度良 くパターニングすることが大きなポイントであり，印刷法を 用いたパターニング技術について検討を進めている。

印刷方法にはインクジェット法，スクリーン印刷法，グラ
ビア印刷法，オフセット印刷法などが挙げられるが，(1)ロー ル to ロールでの印刷工程が可能なこと, (2)ポリピロール塗 料は有機溶剂系であるため, 有機溶剤系塗料の印刷が実用的 なものの 2 点から, ダイレクトグラビア印刷とスクリーン印 刷の 2 方法を中心に開発を進めている(図 3)。当社では，ポ リピロール塗料を各印刷方法に適した印刷特性(粘性・揮発 性など)を有する塗料に調整する技術を有しており，印刷技 術とあわせて開発を進めている。

印刷精度は，ロール to ロールの生産機を用いた量産レベ ルでは，グラビア印刷が L/S (Line/Space $)=200 / 200 \mu \mathrm{m}$ ， ス クリーン印刷が $\mathrm{L} / \mathrm{S}=100 / 100 \mu \mathrm{m}$ までの実績を確認してい る。現在, 電子機器の小型化・高集積化の要求に合わせ，両 印刷方法ともさらなる細線化を検討中である。スクリーン印 刷に抢いては, 枚葉印刷にて, L/S $=75 / 75 \mu \mathrm{m}, \mathrm{L} / \mathrm{S}=$ $50 / 50 \mu \mathrm{m}$ 印刷が可能となった(図 4)。今後も, 印刷加工メー カーの協力を得ながら塗料改良および印刷条件の最適化によ る細線レベルの向上に挑戦していく。

\section{2 ロール to ロール無電解めっきプロセス}

ロール to ロール生産方式での無電解めっき処理は, 通常 の無電解めっきプロセスでは工程が多数存在するため, 困難 であるとされていた。しかし, 本稿で紹介しているポリピロー ル無電解めっき法では, 図 5 に示すような 3 工程の薬液処理 でめっきを行うことができることから，ロール to ロールで の生産方式に適しためっきプロセスであり，この特徴を活か してロール to ロールプロセスによるフィルムの連続めっき 技術の検討を行っている。

当社では, 最大幅 $600 \mathrm{~mm}$ の連続無電解めっきパイロット ラインを導入し，フィルム搬送から薬液の管理まで量産に向 けた検討を進めている。前項で述べたロール to ロール方式
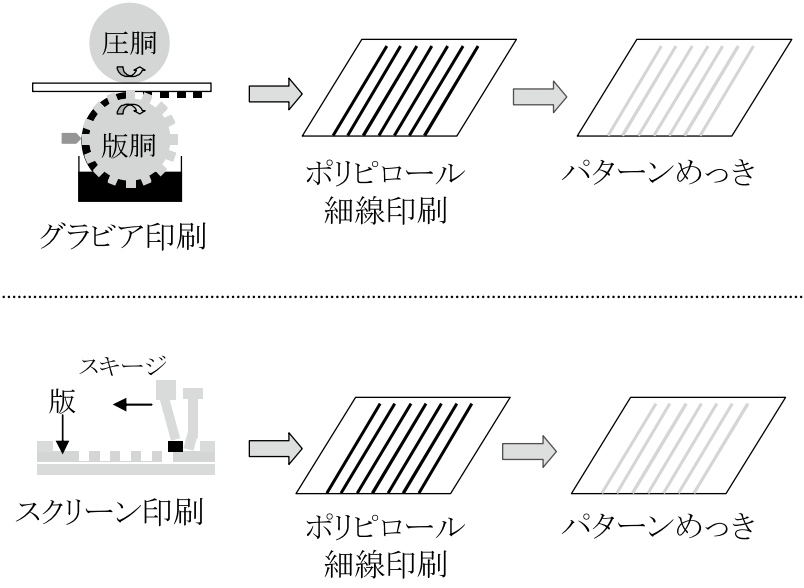

図 3 ポリピロール印刷方法

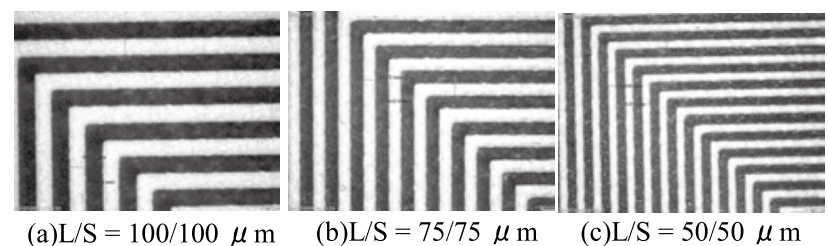

図４パターンめっきサンプル 
でのパターン印刷により得られたフィルムについて，この装 置を用いてめっきすることにより，ロール状のパターンめっ きフィルムを得ることができる。

次項では，この装置を用いて検討している商品の一部を紹 介する。

\section{5. ロール to ロール生産方式を用いたパターンめっき フィルムの応用事例}

\section{1 電磁波シールドフィルム}

電磁波シールドフィルムは，透明基材にポリピロールをパ ターン印刷することで, 印刷部以外の基材部分の透明性が失 われないことを活かした事例であり，格子パターンを中心に 開発を進めている。

電子機器の発展とともに, 我々の身の回りの電磁波発生源 は非常に多くなっている。電子機器から発生する電磁波の悪 影響として, 他の電子機器の誤作動などを引き起こすことが 問題となっている。また, 最近では人体への影響も報告され ている。このため, 電磁波対策は機器の動作信頼性, 安全性 の面から重要な課題となっている ${ }^{12)}$ 。電磁波対策として, 電磁波シールド材が用いられているが, これは金属などの導 電材料や磁性材料が電磁波を反射・吸収する性質を利用した ものである。

そのような電磁波シールド材の 1 つが電磁波シールドフィ ルムであり，PET 基材を用いたディスプレイ用・空用のもの と, 導電布を用いた間仕切りカーテン用などがある。間仕切 りカーテン用の電磁波シールドフィルムは, 視認性, 加工性 が悪く，コストが高いなどの問題がある。そこで, 透明性お よび加工性に優れた基材として, 軟質フィルムのオレフィン と塩ビを選定し, パターンめっきによる導電パターンを形成 することにより, 視認性, 加工性, コストパフォーマンスに 優れた電磁波シールドフィルムを開発した(図6)。

オレフィンや塩ビなどの軟質フィルムへのパターンめっき は, 従来のめっき技術では困難とされており, ポリピロール めっき法の特徴を最大限活用した技術である。加えて, 当社 では, 軟質フィルムの開発・生産を既存事業として行ってお り,コア技術を活かした他社にはない特徴的な商品となって いる。
本方法では, めっき処理により導電性の高い金属を析出さ せることが可能であるため, 無電解めっき処理で対応できる 薄膜の金属層でも $50 \mathrm{~dB}$ 以上(周波数： $100 \mathrm{MHz} \sim 1 \mathrm{GHz}$ )の 高いシールド性能を得ることができる。

また，印刷方法を用いてパターニングを行うため，格子パ ターンの変更が容易であるとともに, グランドパターンやロ ゴなど，設計やデザインの自由度が大きいことも特徵である。

\section{2 アンテナ回路および PET-FPCへの展開}

回路部材への応用の特徵は, フルアディティブ方式による コストダウンと, 低環境負荷である。従来のサブトラクティ ブ方式は, パターン形成のために, レジストの塗布, 現像, エッ チング, レジスト剥離などの煩雑な工程が必要であり, 設備 投資も大きなものとなっていた。本技術では, 汎用の印刷機 を用いて行うため大きな設備投資が必要なく, 無電解めっき 設備のみの導入で生産が可能となる。また, 工程的にも印刷 とめっきの 2 工程であり, 従来法と比べて工程数が大きく減 るため, コストダウンが可能である。また，ポリピロール無 電解めっき法は, 従来のサブトラクティブ法の不要な部位を エッチングなどで削る方法ではなく，必要なところにだけ必 要な量を成長させるアディティブ法であることから環境負荷 の面でも有利である。

さらに，最近アディティブ法以外の回路形成技術として金 属ペースト材料を用いた手法が検討されているが, Ag ペー スト法で現行の $\mathrm{Cu}$ 配線並みの抵抗值を得るためには $150{ }^{\circ} \mathrm{C}$ 以上の高温焼結が必要であり, PET などの基板では耐熱性が 不足するため, 実用性に問題がある。しかしながら, ポリピ

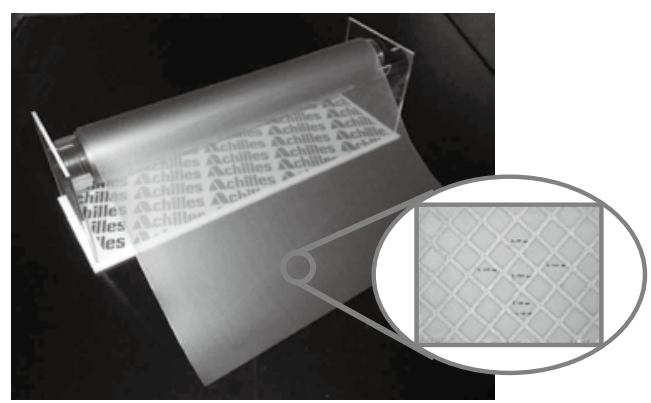

図 6 電磁波シールドフィルム
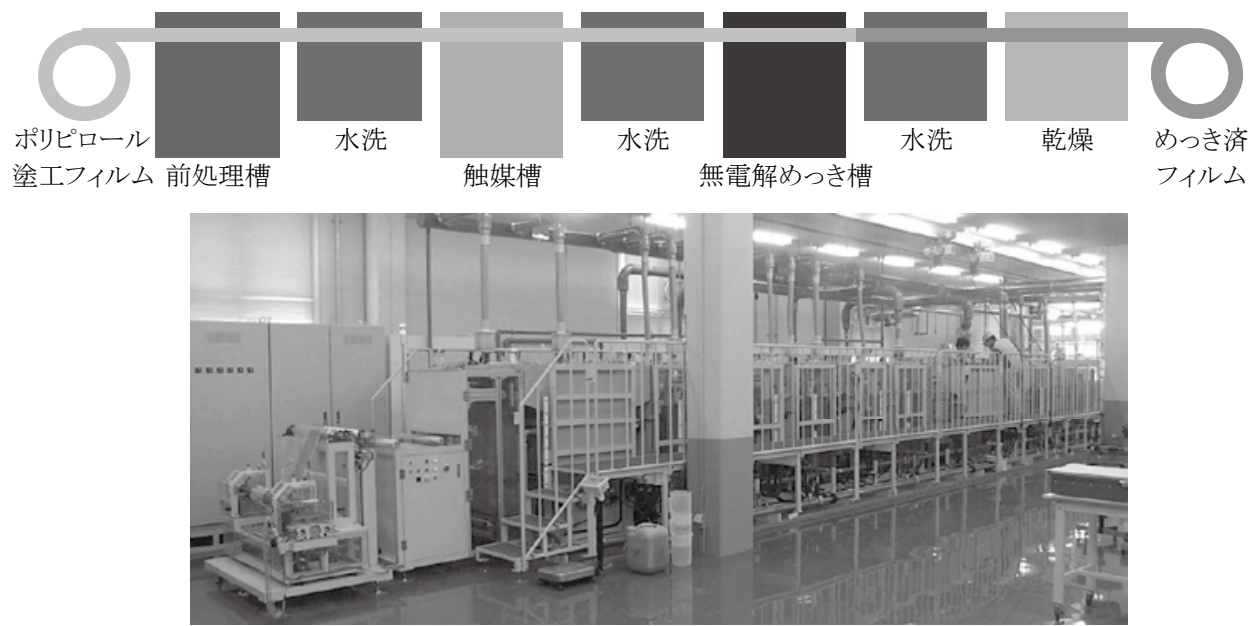

図 5 連続無電解めっきパイロットライン装置概略図 
ロール無電解めっき法は印刷およびめっきプロセスとも $100{ }^{\circ} \mathrm{C}$ 以下の低温処理プロセスが可能であり, さらに，低抵 抗な $\mathrm{Cu}$ 膜が得られることから抵抗值およびマイグレーショ ンの点からも配線材料として有利である。現在, LED 用の フレキシブルプリント基板 (FPC) や RFID アンテナ回路など のアプリケーションへの適応を検討している(図 7)。RFID アンテナに関しては, $\mathrm{UHF}$ 帯アンテナとして, $\mathrm{Al}$ エッチン グ品と同等の通信性能を確認し，各種環境試験もクリアする 評価結果を得ている。

\section{6. 立体めっき}

本章では, これまでのフィルムへのロール to ロールの印刷, 無電解めっき工程とは異なる技術について紹介する。近年, 電子機器の小型化・軽量化・高機能化が急速に進んでおり, 三次元射出成形回路 (Molded Interconnect Devices, MID)など に代表される立体回路の開発や, 筐体への直接配線技術の研 究開発など立体部への導体形成技術が盛んに研究されている。 しかしながら，MIDの代表的な製造方法である 2 色成形を 用いた手法では，工程が煩雑な上に，精密な金型が必要であ り，製造コストが高くなるなどの問題がある。

そこで, パターン印刷一めっき技術の派生技術として, 立 体めっきの技術を開発した。工程は図 8 に示す通りであり， (1)平面基材への PPy インクの印刷, (2)立体形状への賦形, (3)無電解めっきの工程順であり, 無電解めっきで金属膜を形 成する前段階で立体形状に賦形する点がポイントである。

本技術では, 無電解めっきの下地層として, ポリピロール ナノ粒子とバインダー樹脂を混合したポリピロール塗料を用 いていることに注目し, 成形時にめっき下地層を延伸しても 断線しないとともに, 無電解めっきに必要な触媒量の付着が 可能となうようにポリピロール塗料の改良を行った。真空成

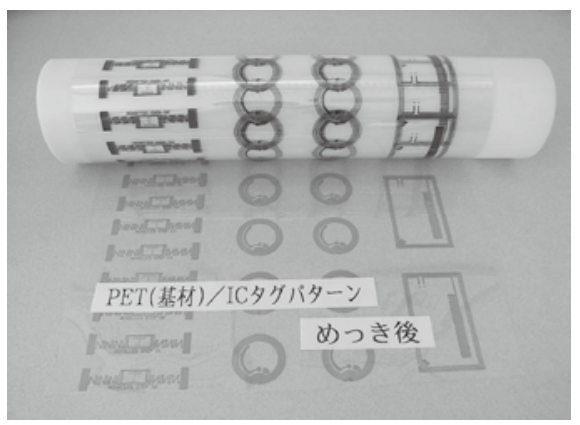

図 7 アンテナパターンめっき

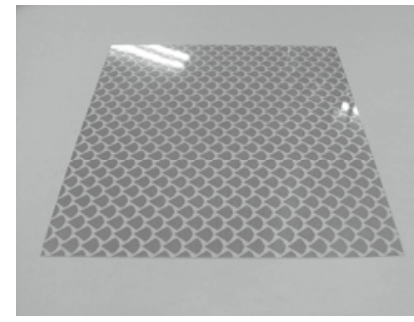

(1) 印刷工程 (平面)

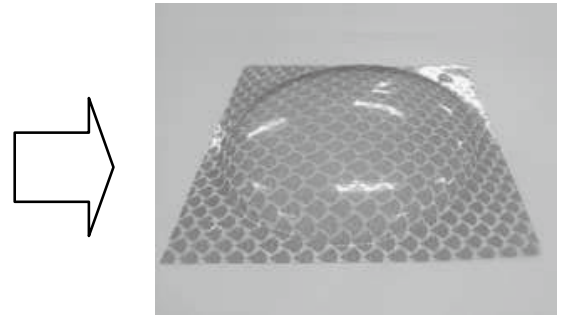

(2) 立体成型工程
形可能な A-PET や PC 上で $3 \sim 5$ 倍程度の絞り加工を行って も，ポリピロール印刷部位が成形に追従して断線しないため, 導通するめっき膜が形成可能なことを確認している。

\section{7. 立体めっきのフィルムインサート成形への適応}

パソコンや携帯電話筐体および自動車のキーレスエント リー, 計器用パネルなどの外装部分の加飾技術として, フィ ルムインサート成形が用いられている。この技術は，PCな どの樹脂シートに文字や柄を加飾印刷後, シートを立体形状 に賦形し，不要な部分を除去し，得られたシートを射出成形 金型中にインサートし，成形する方法である。

この技術の展開として, 加飾印刷後に，シートの非加飾面 にポリピロール塗料を印刷し，両面印刷品を立体形状に賦形 し，めっき処理を施した後，フィルムインサート成形を行う ことにより, 加飾シートと筐体樹脂の間にアンテナやセン サー回路などの導電機能を有した樹脂成形品を従来の製造工 程を活かして作製することができる(図 9)。

これは，これまで紹介してきたポリピロール無電解めっき 法が通常のプラスチックめっきで用いられるような表面粗化 剂を用いることなく密着性の良いめっきが得られるため, めっき前処理での加飾面へのダメージがないこと, 前章で述 べた自由度の高い立体賦形が可能であることの特徵を活かし ている。さらに，めっき面側にインサート成形により樹脂を 被せることにより，めっき面が補強される特徵もある。なお， 外部との接続を必要とする端子部に関しては, 金型を工夫す ることにより接点部を樹脂で覆わない構造とすることも可能 である。

本技術を用いることにより，著しい小型化や軽量化が進む 電子機器において, これまで利用していなかった, 加飾フィ ルムと筐体樹脂の間のスペースにアンテナや配線を設置する ことができるため，省スペース化が容易となるとともに，複 数のアンテナ回路を 1 工程で作製できることや, 大面積のア ンテナを形成できるなど今後の電子機器の導体形成方法とし

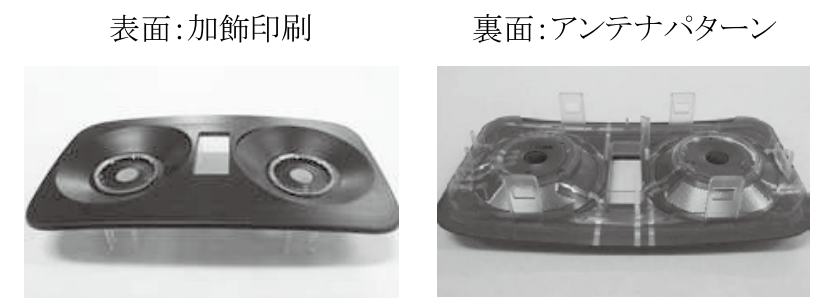

図 9 フィルムインサート成形例

図 8 立体めっき工程図 
てメリットが大きいと考えている。

応用分野としては, パソコン, 携帯電話やキーレスエント リーの筐体配線やアンテナ回路およびタッチパネル回路など 幅広い分野への応用を検討している。

\section{8. まとめ}

本解説文では, ポリピロールナノ分散液を用いた新無電解 めっきプロセスについて, めっき析出および密着のメカニズ ム，技術の特徴を活かしたロール to ロールの生産方式，さ らには，この生産方式を活かした応用展開について報告した。 またこれまでにないプロセスによる立体めっきの技術につ いても紹介した。

その他の応用事例として, 一般的なめっき法では密着が非 常に難しいとされるアラミド繊維へのめっき法の検討も行っ ており，密着性に優れためっき品が得られている。

本技術は，他のめっき技術にはない，パターンめっき，難 めっき素材へのめっき, エッチングレス(クロム酸レス)の特 徵を有しており，適した応用分野は本稿で紹介した以外にも
数多くあると予想され，新規めっき技術の一つとして将来を 期待している。

(Received August 31, 2011）

\section{文献}

1) 英一太 ; プラスチックメタライジング技術, p.15 (シーエム シー出版, 2003).

2 ) 渡辺充広, 杉本将治, 本間英夫 ; 表面技術, 58, 774 (2007).

3 ）芦澤浩樹, 加藤真一郎, 中村洋介; 表面技術, 62, 691 (2011).

4 ) 緒方孝徳; 特許第4385254 (2009).

5 ) 石塚美加子, 緒方孝德 ; 特許第4501030 (2010).

6 ) 石塚美加子, 緒方孝徳; 特許第4501031 (2010).

7 ) M. Ito, J. Harasawa, Y. Nakamura, J. Nishimura ; Koubunnshi Ronbunshu, 65, 594 (2008).

8 ）芦澤弘樹, 中山直樹 ; マテリアルステージ,8, (6), 112 (2008).

9 ）芦澤弘樹 ; プラスチックエージ, 55, (3), 48 (2009).

10）芦澤弘樹, 石黒 正; プラスチックエージ, 57, (3), 44 (2011).

11）田邊裕史; ロール toロール要素技術と可能性, p.3（情報機構, 2008).

12）佐藤利三郎; 電磁環境ハンドブック,p.17 (三松出版, 2009). 